\section{British Computer Development Project}

THE first contract in a four-year $£ 1 \frac{1}{2}$ million joint research project, which is planned to aid long-range British computer development, has been agreed between the Department of Scientific and Industrial Research and Mullard Research Laboratories. This will extend Mullard's existing programme of research in low-temperature computer devices, and, spreading over two years, will cost a total of $£ 100,000$, to which the Department will contribute half. The project is designed to support the British computer industry's already considerable research and development efforts in the face of future widespread technological change. Twelve major British electronics firms are involved, as well as Government laboratories. The National Physical Laboratory at Teddington will act as a co-ordinating centre for the programme as a whole in close association with the Ministry of Aviation's Royal Radar Establishment at Malvern. About two-thirds of the total estimated cost will be borne by the Department of Scientific and Industrial Research, the remaining third being provided by those industrial firms which accept contracts. About one-third of the total sum will be expended in the National Physical Laboratory and the Royal Radar Establishment, and the remaining $£ 1$ million will be spent in industry in the form of development contracts. The first contract is concerned with low-tempera. ture computer devices. It is known already that superconducting stores are feasible, and, in particular, research will be carried out on one form of superconducting element-the cryotron-as a storage device. It is most likely that the cryotron will also be used in the selection circuits of superconductive stores, and in regular arrays of switching circuits such as might occur in stores with special logical properties; sophisticated stores of this type may first become a practical proposition by the use of superconducting techniques. The work to be done under the contract has three aspects. First, the greater understanding of the physics of the cryotron; secondly, the further development of methods for laying down arrays of film with the desired purity and geometric form; and thirdly, the use of the devices in computer stores.

\section{The Applied Scientific Research Corporation of Thailand}

a National Scientific Research Organization is to be set up in Thailand under the leadership of Mr. Frank Nicholls, of Melbourne, who has drawn up the plan for mobilizing Thailand's scientific resources to develop the country's industries.

Mr. Nicholls is international co-operation officer of Commonwealth Scientific and Industrial Research Organization (Australia). He has spent most of the past three years in South-East Asia, mainly investigating the scientific resources of developing countries. He was a member of the Science Commission appointed by the President of Pakistan in 1959 to study that country's scientific work. $\mathrm{He}$ has spent three periods in Thailand preparing the way for the establishment of the Applied Scientific Research Corporation of Thailand, and he drafted the Act recently passed by the Thai National Assembly for that purpose. He has now arrived in Bangkok to head the team of some twenty international experts working under the United Nations, which is establishing the Research Corporation on the lines of the Commonwealth Scientific and Industrial Research Organization. The Research Corporation of Thailand will be concerned with research in agriculture, industry and health. It will examine ways of preparing for the growth of new industry, of supporting existing industries, exploiting mineral resources, finding new uses for plant products, and developing textile and building materials. The Thai Government has taken the initiative for setting up the Research Corporation and has already earmarked ample funds for the work of the initial five-year period. Aid will also be given from the U.N. Special Fund and several international foundations.

\section{Properties and Applications of New Ceramics}

A воокuet, New Ways with Ceramics, issued by the Department of Scientific and Industrial Research and written with the co-operation of the British Ceramic Research Association, outlines the properties and applications of the new and improved ceramics which have been developed to meet special industrial requirements, especially for work at high temperatures (Pp. 12. London: Information Division, Department of Scientific and Industrial Research, 1963). Outstanding among these is boron nitride, which is easily machined, impermeable and has excellent electrical and corrosion-resistance properties up to $1,650^{\circ} \mathrm{C}$. Others described are alumina ceramics, boron carbide, silicon carbide and the cermets, which are complexes of metals and metallic oxides adjusted to bring out desired characteristics.

\section{Bovey Valley Woodlands National Nature Reserve}

The Nature Conservancy has declared the Bovey Valley Woodlands a National Nature Reserve. One of the earliest National Nature Reserves to be acquired (1952) was Yarner Wood in the Bovey Valley, northwest of Bovey Tracey on the eastern edge of Dartmoor. Recent plans for extensive conifer plantations, in some cases replacing scientifically interesting semi-natural woodlands, led the Nature Conservancy to review their Nature Reserve plans and to begin adding a number of further small woodlands to the Yarner nucleus. Three such adjoining woodlands, Rudge (36 acres), Woodash and part of Houndtor Wood (61 acres), have been purchased as a step towards forming an enlarged Bovey Valley Woodlands National Nature Reserve within the Dartmoor National Park. The upper reaches of the River Bovey between Lustleigh Cleave and the little valley including the well-known Becka Falls contain one of the best remaining series of Dartmoor native hardwoods. Rudge Wood occupies one side of the steep slopes at the lower or southern end of the valley and extends through a short succession of wet and boggy fields, carrying much willow, alder and birch, almost to the southern extremity of Houndtor Wood. The latter takes in the very steep northern flank of Houndtor Ridge, which shows the geological transition from the Culm through the meta. morphosed Culm to the Granite, where it adjoins Woodash Wood. Oak is the predominating tree throughout the Reserve, and the two species, pedunculate and sessile, are both well represented. Ash is frequent mainly on the damper alluvial sites and also on granite-derived soils. The woodlands are rich in the smaller forms of plant life, such as mosses, liverworts and lichens, especially along the river margins, where large strewn boulders and damp shade provide a favourable habitat for them. Access to the Reserve away from the public footpath will be by permit only. Applications to visit the Reserve should be addressed to the Regional Officer (South-West), Furzebrook Research Station, Wareham, Dorset.

\section{Last Essays of R. E. Snodgrass}

OVER a period of nearly forty years, R. E. Snodgrass published in the Smithsonian Miscellaneous Collections a series of masterly articles on the anatomy of insects. At the time of his sudden death in September 1962, at the age of eighty-seven, Snodgrass was engaged in writing a kind of encyclopædia of insect anatomy. About a fifth of this had been completed and has now been edited by Dr. A. Glenn Richards and published as a final contribution in the Smithsonian Miscellaneous Collections under the title "A Contribution Toward an Encyclopedia of Insect Anatomy" (146, No. 2. Pp. v+48. Publication 4544. Washington, D.C.: Smithsonian Institution, 1963). This was well worth publishing. It takes the form of a 